\title{
Bacterial pathogens from bed linen used in secondary and tertiary health facilities in Benin city, Nigeria
}

\begin{abstract}
The importance of clean and safe bed linen used in health facilities for patients and staff cannot be over emphasized. A short study was conducted to provide information on the exposure of hospital laundry workers to bacterial pathogens screened from different hospital linen samples. Bacterial isolates were identified and characterized by standard microbiological procedures. Total bacterial count from swab samples taken from different sampling sites ranged from $6.0 \pm 4.0 \times 101-2.1 \pm 0.9 \times 103 \mathrm{CFU} /$ $\mathrm{cm} 2$; with Staphylococcus aureus being the most occurring bacterial isolate. The following bacterial pathogens were isolated; Staphylococcus aureus, Escherichia coli, Pseudomonas aeruginosa, Bacillus cereus, Bacillus subtilis, Serratia sp., Klebsiella sp., Citrobacter freundii, Staphylococcus epidermidis, and Proteus sp. Bacterial pathogens were found on the hospital linens, which could pose health risks to patients and laundry workers of the facilities. These pathogens can easily acquire antibiotic resistance and therefore, there is the need to establish effective infection control strategies.
\end{abstract}

Keywords: bacterial pathogens, linen, antibiotic resistance, health facility, laundry
Volume 6 Issue 2 - 2018

\section{Okareh OT \\ Department of Environmental Health Sciences, University of Ibadan, Nigeria}

Correspondence: Okareh OT, Department of Environmental Health Sciences, Faculty of Public Health, College of Medicine, University of Ibadan, Ibadan, Oyo state, Nigeria, Tel 2348062208354, Email dapsy200I@yahoo.co.uk

Received: January 20, 2018| Published: March 19, 2018

\section{Introduction}

Health Care Workers (HCW) are exposed to various occupational hazards that may threaten their health and safety. ${ }^{1}$ However, exposure to hazardous agents depends upon the job category and the work environment of the $\mathrm{HCW} .^{2}$ Healthcare textiles include bed sheets, blankets, towels, personal clothing, patient apparel, uniforms, gowns, and drapes for surgical procedures. ${ }^{3}$ The importance of a clean environment and linen for optimal patient care has been stressed upon since the very inception of hospitals. Clean bedding and clean clothes create a psychological confidence in the patients and public. ${ }^{4}$

Exposure to blood borne pathogens occur if personnel come into contact with healthcare textiles that are contaminated with blood or other potentially infectious body fluids. ${ }^{5}$ Individuals exposed to contaminated faecal material such as those whose work involves direct contact with fomites such as linen, bed-pans, etc are most at risk of acquiring hepatitis $\mathrm{A}$ in the course of their work. ${ }^{6}$ Contaminated textiles and fabrics may harbour high numbers of microorganisms from the different body substances they are in contact with, such as, blood, skin, stool, urine, vomitus, sputum, and other body tissue and fluid. When contaminated with potentially infective body substances, linen can contain bacterial loads of $10^{6}-10^{8} \mathrm{CFU} / 100 \mathrm{~cm}^{3}$.

Creamer et al. ${ }^{7}$ found methicillin-resistant Staphylococcus aureus (MRSA) ${ }^{8}$ Pseudomonas aeruginosa,${ }^{9}$ vancomycin-resistant Enterococci $(\mathrm{VRE})^{10}$ to have been associated with the spread of pathogens by bed linen as one of the possible environmental routes. Also, there have been reports on bacteria such as Salmonella and Bacillus cereus ${ }^{l l}$ viruses such as hepatitis B; fungi such as Microsporum canis; and parasites such as scabies, being transmitted from contaminated linen to healthcare workers via direct contact and aerosol droplets of lint, generated from sorting and handling linen. ${ }^{3}$ A report of a short study on bacterial pathogens from bed linen used in secondary and tertiary health facilities in Benin City, Nigeria is herewith provided.

\section{Geographical location of study area}

Benin City, the capital of Edo State, has a land area of 1,219.626 km² and is bounded by latitude $6^{\circ} 20^{\prime}$ North and longitude $5^{\circ} 39^{\prime}$ East. The study was conducted in hospitals with laundry departments. They are University of Benin Teaching Hospital-UBTH (tertiary health facility) and secondary care health facilities which include: Central Hospital Benin (CHB), Stella Obasanjo Hospital (SOH), St. Philomena Catholic Hospital (SPCH), Faith Medical Complex (FMC) and Ihenyen Hospital (IH).

\section{Methodology}

Health facilities were randomly selected to represent each of the hospital categories (private secondary, government secondary and government tertiary health facility). The tertiary care facility is a specialized consultative health care facility, usually for inpatients and on referral from a primary or secondary health professional with facility that has personnel and facilities for advanced medical investigation and treatment. Secondary Healthcare facility refers to a second tier of health care facility in Nigeria which patients from primary health care facility are referred to specialists in higher hospitals for treatment. Three designated hospital linen types (clean linen, Used linen but not soiled with blood, urine or faeces and linen soiled with blood, urine or faeces) were used. Culture was prepared using nutrient agar to isolate the bacteria. The culture was produced using $0.5 \%$ peptone, $0.3 \%$ yeast extract, $1.5 \%$ agar, $0.5 \%$ sodium chloride and distille water with $\mathrm{pH}$ adjusted to neutral (6.8) at $25^{\circ} \mathrm{C}$. Morphological characterization of bacterial isolates was carried out using Gram staining procedure. The stained and air-dried slides were examined under microscope using oil-immersion objective technique. Biochemical characterization of bacteria using solubilization index based on colony formation were used in differentiating and 
identifying the types of bacteria. ${ }^{12}$ Following suggested procedure from Bacteriological Analytical Manual of US FDA, CFU/g=(average no. of colonies $\mathrm{x}$ total dilution factor)/ volume plated. ${ }^{13}$

\section{Results}

\section{Total bacterial counts from swab samples}

Total bacterial count from swab samples taken from different sampling sites ranged from $(96.0 \pm 4.00) \times 10^{1}-(92.1 \pm 0.90) \times 10^{3} \mathrm{CFU} /$ $\mathrm{cm}^{2}$. The cultural, morphological and biochemical characterization of isolated bacteria are shown in Table 1, while total bacterial counts from swabs of different linen types sampled from the various hospital categories are presented in Table 2. Linen from the government tertiary hospital showed total bacterial count of $(96.5 \pm 2.8) \times 10^{1} \mathrm{CFU} /$ $\mathrm{cm}^{2}$ for clean linen sample; $(1.3 \pm 0.6) \times 10^{2} \mathrm{CFU} / \mathrm{cm}^{2}$ for dirty linen sample and $(2.1 \pm 0.9) \times 10^{3} \mathrm{CFU} / \mathrm{cm}^{2}$ for soiled linen sample. For linen gotten from the government secondary hospital, total bacterial count of $(3.2 \pm 1.4) \times 10^{2} \mathrm{CFU} / \mathrm{cm}^{2}$ was observed on clean linen sample, $(2.6 \pm 1.4) \times 10^{3} \mathrm{CFU} / \mathrm{cm}^{2}$ on dirty linen sample and $(1.8 \pm 1.1) \times 10^{3} \mathrm{CFU} /$ $\mathrm{cm}^{2}$ on soiled linen sample. Linen from a private secondary hospital showed total bacterial count of $(6.0 \pm 4.0) \times 10^{1} \mathrm{CFU} / \mathrm{cm}^{2}$ for clean linen sample; (1.9 \pm 1.1$) \times 10^{2} \mathrm{CFU} / \mathrm{cm}^{2}$ for dirty linen sample and $(5.3 \pm 3.6)$ $\mathrm{x} 10^{2} \mathrm{CFU} / \mathrm{cm}^{2}$ for soiled linen sample. The identified bacterial isolates included; Staphylococcus aureus, Escherichia coli, Pseudomonas aeruginosa, Bacillus cereus, Bacillus subtilis, Serratia sp., Klebsiella $s p$., Citrobacter freundii, Staphylococcus epidermidis and Proteus sp.

Table I Cultural, morphological and biochemical characterization of isolated bacteria

\begin{tabular}{|c|c|c|c|c|c|c|c|c|c|c|}
\hline \multirow[b]{2}{*}{ Parameters } & \multicolumn{10}{|c|}{ Bacteria isolates } \\
\hline & B I & B2 & B3 & B4 & B5 & B6 & B7 & B8 & B9 & B IO \\
\hline \multirow{2}{*}{\multicolumn{11}{|c|}{$\begin{array}{l}\text { Cultural } \\
\text { Characteristics }\end{array}$}} \\
\hline & & & & & & & & & & \\
\hline Shape & Circular & Round & Circular & Irregular & Irregular & Circular & Circular & Circular & Circular & Round \\
\hline Colour & White & Milky & Green & Cream & Cream & Red & Cream & Cream & White & Milky \\
\hline Size & Large & Small & Small & Large & Large & Large & Large & Medium & Large & Small \\
\hline Elevation & Flat & Raised & Flat & Flat & Flat & Flat & Raised & Convex & Flat & Raised \\
\hline Transparency & Opaque & Translucent & Transparent & Opaque & Opaque & Opaque & Translucent & Opaque & Opaque & Opaque \\
\hline \multicolumn{11}{|l|}{$\begin{array}{l}\text { Morphological } \\
\text { characteristics }\end{array}$} \\
\hline Gram stain & + & - & - & + & + & - & - & - & + & - \\
\hline Cell type & Cocci & Cocci & Rod & Rod & Rod & Rod & Rod & Rod & Cocci & Rod \\
\hline Cell arrangement & Chains & Clusters & Single & Single & Single & Single & Single & Single & Chains & Chains \\
\hline Spore staining & - & - & - & + & + & - & - & - & - & - \\
\hline \multicolumn{11}{|l|}{ biochemical test } \\
\hline Urease & & & - & - & - & - & - & - & & + \\
\hline Indole & & & - & - & - & - & - & - & & - \\
\hline Acid fast & - & - & - & - & - & - & - & - & - & - \\
\hline Citrate utilization & - & + & + & - & + & + & + & + & - & + \\
\hline $\begin{array}{l}\text { Catalase } \\
\text { production }\end{array}$ & + & + & - & - & - & - & + & & - & - \\
\hline Motility & - & + & + & + & + & + & + & + & - & + \\
\hline Methyl red & - & + & + & - & - & - & - & + & - & - \\
\hline Vogues Paskeur & - & + & - & - & - & - & + & + & - & + \\
\hline Coagulase & + & - & - & - & - & - & - & - & - & - \\
\hline Starch hydrolysis & + & + & + & + & + & + & - & + & + & + \\
\hline Oxidase & - & - & + & + & + & + & - & - & - & - \\
\hline $\begin{array}{l}\text { Hydrogen } \\
\text { sulphide }\end{array}$ & - & - & - & - & - & - & - & + & - & - \\
\hline \multirow{2}{*}{\multicolumn{11}{|c|}{$\begin{array}{l}\text { Oxidative } \\
\text { fermentation } \\
\text { test }\end{array}$}} \\
\hline & & & & & & & & & & \\
\hline Glucose & + & + & + & + & + & + & + & + & + & + \\
\hline Fructose & & & + & + & + & + & + & + & & - \\
\hline Maltose & & & & + & + & + & + & + & & + \\
\hline Lactose & + & - & + & - & - & - & + & + & + & - \\
\hline $\begin{array}{l}\text { probable } \\
\text { identity }\end{array}$ & $\begin{array}{l}\text { Staphylococcus } \\
\text { aureus }\end{array}$ & $\begin{array}{l}\text { Escherichia } \\
\text { coli }\end{array}$ & $\begin{array}{l}\text { Pseudomonas } \\
\text { aeruginosa }\end{array}$ & $\begin{array}{l}\text { Bacillus } \\
\text { cereus }\end{array}$ & $\begin{array}{l}\text { Bacillus } \\
\text { subtilis }\end{array}$ & $\begin{array}{l}\text { Serratia } \\
\text { sp. }\end{array}$ & Klebsiella sp. & $\begin{array}{l}\text { Citrobacter } \\
\text { freundii }\end{array}$ & $\begin{array}{l}\text { Staphylococcus } \\
\text { epidermidis }\end{array}$ & $\begin{array}{l}\text { Proteus } \\
\text { sp. }\end{array}$ \\
\hline
\end{tabular}


Table 2 Total bacterial counts from swab samples (CFU/cm2)

\begin{tabular}{llll}
\hline \multirow{2}{*}{ Linen type } & \multicolumn{2}{l}{ Sampling sites } & \\
\cline { 2 - 4 } & GT & GS & PS \\
\hline Clean linen & $(6.5 \pm 2.8) \times 10^{1}$ & $(3.2 \pm 1.4) \times 10^{2}$ & $(6.0 \pm 4.0) \times 10^{1}$ \\
Dirty linen & $(1.3 \pm 0.6) \times 10^{2}$ & $(2.6 \pm 1.4) \times 10^{3}$ & $(1.9 \pm 1.1) \times 10^{2}$ \\
Soiled linen & $(2.1 \pm 0.9) \times 10^{3}$ & $(1.8 \pm 1.1) \times 10^{3}$ & $(5.3 \pm 3.6) \times 10^{2}$ \\
\hline
\end{tabular}

Key: PS, private secondary health facility; GS, government secondary health facility; GT, government tertiary health facility

\section{Occurrence and distribution of bacterial isolates among different samples}

The percentage occurrence of identified bacterial isolates showed $P$. aeruginosa as the least occurring isolate $(22.22 \%)$ and $S$. aureus as the most occurring isolate (77.78\%). Serratia sp., C. freundii, $S$. epidermidis and Proteus sp. were observed to occur as $44.44 \%$ of sampled linen, while B. Subtilis and Klebsiella sp. were observed to occur in $55.56 \%$ of sampled linen. B. Cereus and E. coli however, were observed to occur in $66.67 \%$ of sampled linen (Table 3 ).

Table 3 The distribution of identified bacterial isolates among the different sampling sites

\begin{tabular}{|c|c|c|c|}
\hline \multirow{2}{*}{ Linen type } & \multicolumn{3}{|l|}{ Sampling sites } \\
\hline & GT & GS & PS \\
\hline Clean linen & $\mathrm{BI}, \mathrm{B} 4, \mathrm{~B} 5, \mathrm{~B} 9$ & B5, B9 & B4, B7 \\
\hline Dirty linen & BI, B2, B4, B5, B7, B9, BIO & BI, B2, B4, B6, B7, B9 & $\mathrm{BI}, \mathrm{B} 2, \mathrm{~B} 3, \mathrm{~B} 4, \mathrm{~B} 5, \mathrm{~B} 6, \mathrm{~B} 8, \mathrm{BI} 0$ \\
\hline Soiled linen & $\mathrm{BI}, \mathrm{B} 2, \mathrm{~B} 3, \mathrm{~B} 4, \mathrm{~B} 6, \mathrm{~B} 7, \mathrm{~B} 8, \mathrm{~B} / 0$ & $\mathrm{BI}, \mathrm{B} 2, \mathrm{~B} 6, \mathrm{~B} 8, \mathrm{~B} 10$ & $\mathrm{BI}, \mathrm{B} 2, \mathrm{~B} 5, \mathrm{~B} 7, \mathrm{~B} 8$ \\
\hline
\end{tabular}

Key: PS, private secondary health facility; GS, government secondary health facility; GT, government tertiary health facility; BI, S. aureus; B2, E. coli; B3, P. aeruginosa; B4, B. cereus; B5, B. subtilis; B6, Serratia sp.; B7, Klebsiella sp.; B8, C. freundii; B9, S. epidermidis; BI 0, Proteus sp.

\section{Discussion}

The total bacterial count on contaminated laundry (dirty and soiled) was higher than on clean laundry. This finding supports a report by Sehulster et al., ${ }^{3}$ who noted that contaminated textiles and fabrics may harbour high numbers of microorganisms as a result of contact with different body substances such as, blood, skin, stool, urine, vomitus, sputum, and other body tissue and Fluid. It should also be noted that clean (laundered) textile was also observed to contain some bacterial pathogens, but low in estimation. This calls for proper disinfection of linen used. Identified bacterial isolates include; Staphylococcus aureus, Escherichia coli, Pseudomonas aeruginosa, Bacillus cereus, Bacillus subtilis, Serratia sp., Klebsiella sp., Citrobacter freundii, Staphylococcus epidermidis and Proteus sp. There have been reports of methicillin-resistant Staphylococcus aureus (MRSA), ${ }^{8}$ Pseudomonas aeruginosa $a^{9}$ and Bacillus cereus ${ }^{11}$ to have been associated with hospital bed linens. Furthermore, a survey of bacterial contamination of hospital staff apparel in use in Anambra State, Nigeria, was carried out to determine the extent of contamination by clinically important bacteria. The potentially pathogenic bacteria isolated were Proteus spp., Pseudomonas aeruginosa and Staphylococcus aureus,,$^{14}$ while a microbiological analysis of swabs taken from the cuffs and pocket mouths of physicians' white coats in an acute care hospital showed that $91.3 \%$ of the coats had bacterial contamination, specifically Staphylococcus aureus and gram-negative Bacilli which were resistant to nearly all of the antibiotics tested. ${ }^{15}$

\section{Conclusion and recommendation}

Bacterial pathogens were found on hospital linen, which could pose danger to laundry workers responsible for washing them and other health workers using them. These pathogens can easily acquire antibiotic resistance and therefore calls for the need to establish an effective infection control policy that incorporates the welfare of hospital laundry workers and other healthcare workers in all healthcare facilities.

\section{Acknowledgements}

None.

\section{Conflict of interest}

The author declares no conflict of interest.

\section{References}

1. Harrington JM, Gill FS, Aw TC, et al. Occupational health. 4th ed Oxford, UK: Blackwell Pup; 2000;44(2):3-347.

2. Russi MB, Howarth MV, et al. Occupational medicine in health care industry. Text Book of Clinical Occupational and Environmental Medicine. 2nd ed. USA: Elsevier Inc; 2005. 245 p.

3. Centers for Disease Control and Prevention. Guidelines for environmental infection control in health-care facilities. MMWR Recomm Rep. 2003;52(RR-10):1-42.

4. Manuel M, Daphnie L, D'cunha S, et al. A study to assess awareness on occupational health hazard among laundry workers. Muller J Med Sci Res. 2015;6(1):40-44.

5. Pyrek KM. Infection Control Today: Preventing Sharps Injuries and Blood-borne Pathogen Exposures in the Healthcare Laundry. Informa Exhibitions LLC; 2015. 12 p.

6. Hofmann F, Wehrle G, Berhold H, et al. Hepatitis A as an occupational hazard. Vaccine. 1992;10(1):S82-84.

7. Creamer E, Humphreys H. The contribution of beds to healthcareassociated infection: The importance of adequate decontamination. $J$ Hosp Infect. 2008;69(1):8-23. 
8. Shiomori T, Miyamoto H, Makishima K, et al. Evaluation of bed-makingrelated airborne and surface methicillin-resistant Staphylococcus aureus contamination. J Hosp Infect. 2002;50(1):30-35.

9. Panagea S, Winstanley C, Walshaw MJ, et al. Environmental contamination with an epidemic strain of Pseudomonas aeruginosa in a Liverpool cystic fibrosis centre, and study of its survival on dry surfaces. J Hosp Infect. 2005;59(2):102-107.

10. Bonten MJM, Hayden MK, Nathan C, et al. Epidemiology of colonisation of patients and environment with vancomycin-resistant Enterococci. Lancet. 1996;348(9042):1615-1619.

11. Barrie D, Hoffman PN, Wilson JA, et al. Contamination of hospital linen by Bacillus cereus. Epidemiol Infect. 1994;113(2):297-306.
12. Christopher K, Bruno E. Identification of bacterial species. In: O’Donnell MA, editor. Tested studies for laboratory teaching. Association for Biology Laboratory Education. 2003;24:103-130.[

13. American Public Health Association. Compendium of Methods for the Microbiological Examination of Foods. 2nd ed. Washington, USA: APHA; 1984.

14. Orji MU, Mbata TI, Kalu OU, et al. Isolation of Pathogenic Bacteria from Hospital Staff Apparel in Nigeria. Malawi Med J. 2005;17(4):128-130.

15. Uneke CJ, Ijeoma PA. The Potential for Nosocomial Infection Transmission by White Coats Used by Physicians in Nigeria: Implications for Improved Patient Safety Initiatives. World Health Popul. 2010;11(3):1-6. 